\title{
Consumption of elicited soybean sprout flour increases calcium level in serum of ovariectomized rats
}

\author{
Siti Aminah*, Suparmo**, Sri Naruki**, and Hastari Wuryastuty***
}

\section{ABSTRACT}

\section{BACKGROUND}

The decline in estrogens could lead to an imbalance of bone formation and absorption as well as bone mineralization. Phytoestrogens are known to have the potential to maintain bone health. Calcium and phosphorus are essential components for bone mineralization. This study aimed to investigate the effect of soybean sprout flour consumption on serum calcium and phosphorus levels in ovariectomized rats.

\section{METHODS}

A randomized post-test-only control group design involving 25 female Sprague-Dawley rats aged 2 months, which were divided into five groups: (i) normal controls on standard feed diet AIN-93 (C-N), (ii) ovariectomy controls on standard feed diet (OVX -N); (iii) ovariectomized rats on standard feed diet + ethinylestradiol (OVX -E), (iv) ovariectomized rats on standard feed diet + soybean flour (OVX -S); (v) ovariectomized rats on standard feed diet + soybean sprout flour (OVX -SS). The rats were treated for 6 weeks, then on the last day of treatment blood sampling was conducted. Analysis of calcium and phosphorus in serum was performed using the Arsenazo III photometric method. Data were analyzed using one-way Anova.

\section{RESULTS}

Mean serum calcium level was highest in the OVX-SS group $(12.59 \mathrm{mg} /$ $\mathrm{dL} \pm 1.32$ ), while mean serum phosphorus level was highest in the $\mathrm{C}-\mathrm{N}$ group $(1.708 \mathrm{mg} / \mathrm{dL} \pm 0.28)$. Soybean sprout flour consumption had a significant effect on serum calcium levels $(\mathrm{p}=0.019)$, yet it had no effect on body weight and serum phosphorus levels of the rats.

\section{CONCLUSION}

Consumption of soybean sprout flour could positively affect serum calcium levels in rats.

Keywords : Calcium, phosphorus, serum, rat ovariectomy, soybean sprout
*Department of Food and

Technology, Faculty of Nursing and Health Science, Semarang

Muhammadiyah University Semarang

**Department of Food and

Agricultural Product Technology,

Faculty of Agricultural Technology, Gadjah Mada University, Yogyakarta ***Department of Internal Veterinary Medicine, Faculty of Veterinary Medicine, Gadjah Mada

UniversityYogyakarta

\section{Correspondence :}

Siti Aminah, S.TP., M.Si

Faculty of Nursing and Health Science, Semarang Muhammadiyah University Semarang (UNIMUS)

Jl. Kedungmundu Raya No. 18

Semarang 50273

Phone: +6224 76740295

Fax : +6224 76740291

Email: sitiaminah@unimus.ac.id

Date of first submission, March 29, 2017

Date of final revised submission, August 4, 2017

Date of acceptance, August 7, 2017

This open access article is distributed under a Creative Commons AttributionNon Commercial-Share Alike 4.0 International License

Cite this article as: Aminah S, Suparmo, Naruki S, Wuryastuty H. Consumption of elicited soybean sprout flour increases calcium level in serum of ovariectomized rats. Univ Med 2017;36:94-101. doi: 10.18051/UnivMed.2017.v36.94101 


\section{INTRODUCTION}

Bone is a dynamic tissue constantly performing regenerating activity, i.e. absorption and replacement with new cells at a constant rate. ${ }^{(1)}$ The main minerals of bone are calcium and phosphorus (50-70\%) in the form of calcium hydroxyapatite [CA10 (PO 4) $6(\mathrm{OH}) 2$ ], while the rest are an organic matrix (20-40\%); water $(5-10 \%)$, and fat $(3 \%) .^{(2,3)}$ Both $\mathrm{Ca}$ and $\mathrm{P}$ are important minerals in the formation and metabolism of bone. ${ }^{(4)}$ Serum Ca status is associated with $\mathrm{Ca}$ absorption in the intestine, reabsorption in the kidneys, and resorption from bone. ${ }^{(5,6)}$

Other components involved in bone formation and metabolism include estrogen, parathyroid hormone, and vitamin D. Estrogen plays an important role in bone metabolism, by promoting bone formation through increased activity of osteoblasts and by in habiting bone calcium resorption. ${ }^{(3)}$ Aloia and Shieh ${ }^{(7)}$ state that estrogen plays a role in calcium absorption through trans cellular pathways regulated by transient receptor potential vanilloid type 6 (TRPV6) channel. TRPV6 is expressed from calcitriol and vitamin $\mathrm{D}$ receptor (VDR). Therefore, estrogen plays a very important role in bone metabolism. Deficiency of estrogen in postmenopausal women could lead to increased resorption of $\mathrm{Ca}$ and $\mathrm{P}$ in bone, decreased absorption of $\mathrm{Ca}$ in the intestine, and increased excretion of $\mathrm{Ca}$ and $\mathrm{P}$. Imbalances of absorption and excretion of $\mathrm{Ca}$ and $\mathrm{P}$ could result in decreased $\mathrm{Ca}$ and increased $\mathrm{P}$ in the blood. The imbalance in the absorption and excretion of $\mathrm{Ca}$ and $\mathrm{P}$ in postmenopausal women can lead to decreased bone density so that the bone becomes brittle and easily fractured. ${ }^{(8)}$

Several studies have shown that serum calcium levels are significantly decreased in postmenopausal women. Deficiency of estrogens causes calcium loss due to decreased absorption of calcium in the intestine and increased calcium resorption in the kidney. ${ }^{(9-11)}$ Ovariectomy causes increased excretion of calcium and phosphorus, resulting in decreased serum calcium and phosphorus levels in ovariectomized rats. ${ }^{(12)}$

Oneway to treat estrogen deficiency in postmenopausal women is by means of oral hormone replacement therapy (HRT). However, the use of HRT in the long term has aless favorable influence on women's health, including triggering of cancer. ${ }^{(13)}$ The alternative to synthetic hormone replacement is treatment with phytoestrogens. ${ }^{(14)}$ Soy is one of the food sources containing phytoestrogens, i.e. isoflavones, which have the potential of estrogen in bone metabolism. ${ }^{(15)}$ Besides as a source of isoflavones, soy contains compounds, which could inhibit $\mathrm{Ca}$ absorption, e.g.phytic acid. ${ }^{(16)}$ the phytic acid component of soybeans could be reduced through germination. Germinated soybeans have been proven to have better bioactive components than do soybeans. Soybean sprouts are soy beans germinating under controlled conditions. Compared to mature soybeans, soybean sprouts contain a substantial amount of protein and much higher amounts of various vitamins. ${ }^{(17)}$ Changes occurring in the germinated soybeans include increased levels of vitamin $\mathrm{C}, \alpha$-tocopherol, crude fiber, and protein. ${ }^{(18)}$ Components of secondary metabolites such as polyphenols, isoflavones, phytosterols, flavonoids, polyphenols and the antioxidant capacity are also increased. ${ }^{(19)}$

Mugisha ${ }^{(20)}$ reported that phytoestrogen components, especially soy and soybean sprout isoflavones provide are beneficial for bone health. Phytoestrogens trigger protein synthesis, decrease the osteoprotegerin/receptor activator of nuclear factor-kappa $\beta$ ligand (OPG/RANKL) ratio, and mineralization by osteoblasts. Phytoestrogen administration could inhibit the differentiation and activation of osteoclasts. ${ }^{(21)}$ Phytoestrogens directly or indirectly affect the absorption of calcium. Miao et al. ${ }^{(12)}$ suggested that administration of isoflavones to ovariectomized rats could prevent osteoporosis through inhibition of calcium loss and improvement of parathyroid hormone (PTH), which acts as a regulator of calcium absorption. 
The process of elicitation is known to be able to increase secondary metabolite components of soybean sprouts. ${ }^{(22)}$ According to Saini et al. ${ }^{(23)}$ elicited soybean sprouts have better nutraceutical potential than control sprouts. $\mathrm{NaCl}$ is one of the abiotic elicitors, which could be used to improve the secondary metabolite components of soybean sprouts. ${ }^{(24,25)}$

Soybean sprouts are likely to have a better potential than ungerminated soybeans for bone health, especially in postmenopausal women. So far, there have been no reports about the effects of soybean sprout flour on $\mathrm{Ca}$ and $\mathrm{P}$ levels in ovariectomized rats. This research aimed to study the potential effect of soybean sprouts after elicitation on $\mathrm{Ca}$ and $\mathrm{P}$ in the serum of postmenopausal rats. The postmenopausal models were obtained through ovariectomy (ovary removal operation) of the rats, which were then expected to experience estrogen deficiency. ${ }^{(26)}$

\section{METHODS}

\section{Research design}

This research was of randomized post-testonly control group design. Research was conducted at the preclinical unit of the Integrated Research and Testing Laboratory (LPPT), Gadjah Mada University [Universitas Gadjah Mada (UGM)], Yogyakarta. The study was conducted from February until May 2015.

\section{Subjects of study}

The experimental animals used were female Sprague Dawley rats aged 2 months obtained from the preclinical unit of LPPT, UGM, Yogyakarta.

\section{Sample size determination}

The sample size was determined based on the formula: $\mathrm{S}=(\mathrm{t}-1)(\mathrm{r}-1) \geq 15$, where $\mathrm{t}$ is the number of groups, and is the number of animals per group. ${ }^{(27)}$ This study used three treatment groups in addition to two control groups, so that $\mathrm{t}=5$, giving $(5-1)(\mathrm{r}-1) \geq 15$, and resulting in (5-
1) $(5-1)=16$. Therefore the number of rats $(r)$ in each group was 5 . The rats were randomly divided into the following 5 groups: (i) normal control group on standard feed diet AIN-93M (C-N); (ii) ovariectomy control group (OVX C) on standard feed diet AIN-93M; (iii) ovariectomy group on standard feed diet AIN$93 \mathrm{M}+$ ethinylestradiol (OVX -E), (iv) ovariectomy group on standard feed diet AIN$93 \mathrm{M}+$ soybean flour (OVX -S); and (v) ovariectomy group on standard feed diet AIN$93 \mathrm{M}+$ soybean sprout flour (OVX -SS).

\section{Preparation of the postmenopause rat model}

After the rats had been adapted for 1 week, in each of the four groups of rats (ii, iii, iv and v), their ovaries were surgically removed (ovariectomy). Before the surgery, the rats were first anesthetized using a mixture of ketamine $10 \%$ at a dose of $5 \mathrm{mg} / \mathrm{kgBW}$ and xylazine $2 \%$ at a dose of $5 \mathrm{mg} / \mathrm{kgBW}$, which was injected intramuscularly. ${ }^{(28)}$

\section{Preparation of soybean sprout flour}

The soybeans used in this study were of the local yellow Anjasmoro soybean variety obtained from the Research Institute for Legumes and Tubers, Malang, East Java. The soybean germination process began with the elicitation process (soaking) using a $2 \% \mathrm{NaCl}$ solution for 8 hours. Germination was conducted for 36 hours in the dark ${ }^{(29)}$ then the sprouts were dried and powdered.

\section{Intervention}

Evaluation of the potential influence of soybean sprouts on the serum levels of $\mathrm{Ca}$ and $\mathrm{P}$ of the rats was done by comparing the groups of rats receiving either ethinylestradiol (Lynoral $0.05 \mathrm{mg} /$ tablet, Sydna Farma), soybean flour, or soybean sprout flour (groups iii; iv; and v respectively), as well as the two control groups (normal and ovariectomized controls). All rats received the standard feed AIN-93M. All materials for intervention were prepared in soluble form. All treatments were given orally 
for 6 weeks, with the amount of soybean flour and soybean sprout flour given based on a dose of $10 \mu \mathrm{g} / \mathrm{g} \mathrm{BW} /$ day of isoflavones. The rats in group iii were treated with ethinylestradiolat 30 $\mu \mathrm{g} / \mathrm{kg} \mathrm{BW} /$ day.

During the experiment, the weight of each rat (expressed in grams) was checked every 2 days. The dose was adjusted to the weight gain of the rats. Blood samples of $\pm 2 \mathrm{~mL}$ were taken on the last day of treatment using a microhematocrit tube through the orbital sinus. Blood serum was separated using a centrifuge (Thermo Scientific, micro legend 12) at a speed of $3000 \mathrm{rpm}$ for $15 \mathrm{~min}$ and then stored at $-20^{\circ}$ $\mathrm{C}$ until the laboratory analysis was performed.

\section{Laboratory analysis}

Analysis of serum $\mathrm{Ca}$ and phosphorus was carried out using a reagent kit (DiaSys, Germany) for the photometric Arsenazo III method. The analytical procedures were done according to the Dyasis kit manual. Ca levels were read using micro lab Spectrophotometer 300 (Elitech, France), at wave length $(\lambda)$ of 620 $\mathrm{nm}$, while the $P$ levels were read at $\lambda$ of $340 \mathrm{~nm}$. Both $\mathrm{Ca}$ and $\mathrm{P}$ levels were expressed in $\mathrm{mg} / \mathrm{dL}$.

\section{Statistical analysis}

The analysis of weight data as well as the serum levels of $\mathrm{Ca}$ and $\mathrm{P}$ were performed using one-way Anova with SPSS version 18. For the test results showing a significant effect, the test was continued with the LSD multiple comparison test. The significance level used was a p-value of $<0.05$.

\section{Ethical clearance}

This study obtained ethical clearance from the Commission on Ethical Clearance LPPT UGM. No: 206/KEC-LPPT/XII/014.

\section{RESULTS}

\section{Body weight (BW)}

The mean BW of the rats may be seen in Table 1. The results of statistical analysis showed that there was no difference in the BW of the rats in all experimental groups. Table 1 shows that the post treatment BW of the rats in all groups was increased. When compared with the BW of the rats in the normal control group, all treatment groups had increased BW

\section{Serum calcium and phosphorus levels}

Serum calcium and phosphorus levels of the rats are shown in Table 2. The treatment group receiving soybean sprouts showed the highest mean calcium level $(12.59 \pm 1.32 \mathrm{mg} / \mathrm{dL})$, whereas the group treated with soybean flour showed the lowest mean calcium level (10.97 \pm $0.68 \mathrm{mg} / \mathrm{dL}$ ). The highest phosphorus levels were in the normal control group $(1.708 \pm 0.28 \mathrm{mg} /$ $\mathrm{dL})$, while the lowest levels were in the group receiving soybeans $(1.34 \pm 0.29 \mathrm{mg} / \mathrm{dL})$. The results of further statistic tests (Table 2) showed that there was a significant effect of treatment on Ca levels in serum ( $p=0.019)$, yet there was no significant effect on phosphorus levels in serum and the $\mathrm{Ca} / \mathrm{P}$ ratio $(\mathrm{p}=0.194)$. Multiple comparisons analysis was done for calcium levels to determine which groups had significant differences. The OVX-SS group (treatment with soybean sprout flour) was significantly different from the other 4 groups

\section{DISCUSSION}

The study demonstrated that the highest increase in BW was in the treatment group receiving additional soy flour. Although there was no difference in terms of BW increases based on statistical test results, in the group of ovariectomized rats there was a tendency to a higher percentage of BW than that in the normal control group. The results obtained in this study do not agree with those reported by Park et al. ${ }^{(15)}$ and Shin et al. ${ }^{(30)}$ that there was a significant increase of BW in the group of ovariectomized rats compared to that in control rats. Ovariectomy is associated with increased abdominal fat in rats. The increase in BW in the BB-S OVX group was higher than that in the 
Table 1. Body weight of rats at baseline and end of treatment

\begin{tabular}{|c|c|c|c|c|c|c|}
\hline \multirow{2}{*}{ Variable } & \multicolumn{5}{|c|}{ Groups } & \multirow{2}{*}{$\mathbf{p}$} \\
\hline & NC & OVX-C & OVX-E & OVX-S & OVX-SS & \\
\hline Baseline & $109.70 \pm 12.5$ & $107.77 \pm 14.33$ & $107.98 \pm 16.24$ & $107.87 \pm 14.10$ & $107.98 \pm 4.17$ & 0.951 \\
\hline Pretreatment & $138.47 \pm 7.06$ & $138.21 \pm 8.29$ & $140.00 \pm 13.40$ & $134.67 \pm 15.57$ & $141.64 \pm 16.15$ & 0.901 \\
\hline Postreatment & $196.27 \pm 18.66$ & $200.81 \pm 26.38$ & $214.32 \pm 21.13$ & $186.62 \pm 14.26$ & $206.47 \pm 16.17$ & 0.128 \\
\hline
\end{tabular}

Note: $\mathrm{NC}=$ normal controls; $\mathrm{OVX}-\mathrm{C}=$ ovariectomized controls; OVX-E $=$ ovariectomized rats on estradiol; OVX-S $=$ ovariectomized rats on soybean flour; OVX-SS = ovariectomized rats on soybean sprout flour. Data were analyzed with one-way Anova.Values presented are mean $\pm \mathrm{SD}$. Baseline $=$ body weight of first day of adaptation; pretreatment $=$ body weight after recovery from ovariectomy ( 2 weeks maintenance). postreatment =body weight at the end of treatment

other groups of ovariectomized rats. It was likely influenced by the greater amount of soybean flour than the amount of soybean sprout flour given. This was due to the treatment being based on the dose of isoflavones (daidzein), while the soy daidzein level $(2.97 \mathrm{mg} / \mathrm{g} \mathrm{db})$ was lower than that in the soybean sprouts $(6.33 \mathrm{mg} / \mathrm{g} \mathrm{db})$. The rise in body weight in the OVX-E group was lowest, because only a solution of ethynilestradiol was given as estrogen source, so there was no contribution of nutrients such as in soybeans and soybean sprouts. The administered mean daily amounts of soybean flour and soybean sprout flour at the beginning of treatment were $0.44 \mathrm{~g}$ and $0.21 \mathrm{~g}$, respectively, while at the end of treatment the amounts were $0.66 \mathrm{~g}$ and $0.32 \mathrm{~g}$, respectively. The possibility exists that nutrients from both ingredients contributed to the body weight.

Table 2 shows that the levels of serum $\mathrm{Ca}$ and $\mathrm{P}$ of the ovariectomized groups were lower than those of the normal control group, except in the OVX-SS group, where serum Ca levels were higher than those of controls. Several researchers have shown an association between $\mathrm{Ca}$ and $\mathrm{P}$ levels in ovariectomized rats, as reported by Mioa et al. ${ }^{(12)}$ that ovariectomy increases urinary excretion of $\mathrm{Ca}$ and $\mathrm{P}$, and lowers the levels of $\mathrm{Ca}$ and $\mathrm{P}$ in the serum of the rats. Likewise, Unis et al. ${ }^{(8)}$ reported that ovariectomized rats experience decreased serum $\mathrm{Ca}$, but no change in serum $\mathrm{P}$ levels. It is also reported by Parket al. ${ }^{(15)}$ and Unis et al. ${ }^{(8)}$ that mean serum levels of the minerals $\mathrm{Ca}, \mathrm{P}$ and $\mathrm{Mg}$ in ovariectomized rats were significantly decreased compared to those of the non-ovariectomized control group. Increased excretion of $\mathrm{Ca}$ and $\mathrm{P}$ is likely associated with the role of estrogen on intestinal calcium absorption. The fall in estrogen may be the cause of the low absorption of $\mathrm{Ca}$ and $\mathrm{P}$ in the intestine, so increasing the excretion of $\mathrm{Ca}$ and $\mathrm{P}$ in the feces and urine. This explains why there is a relationship between the decrease of estrogen in the blood circulation and falling of $\mathrm{Ca}$ and $\mathrm{P}$ absorption in the intestinal tract of ovariectomized rats.

The decrease in serum calcium status is associated with decreased ovarian function in producing estrogen. Estrogen could give either direct or indirect influence on the bone remodeling

Table 2. Calcium and phosphorus levels in serum of rats after intervention for 6 weeks

\begin{tabular}{lcccccc}
\hline \multirow{2}{*}{ Variable } & \multicolumn{5}{c}{ Groups } & p \\
\cline { 2 - 6 } & NC & OVX-C & OVX-E & OVX-S & OVX-SS & 0.019 \\
\hline $\begin{array}{l}\text { Serum calcium } \\
(\mathrm{mg} / \mathrm{dL})\end{array}$ & $11.36 \pm 0.46$ & $11.01 \pm 0.65$ & $11.03 \pm 0.50$ & $10.97 \pm 0.68$ & $12.59 \pm 1.32^{*}$ & \\
$\begin{array}{l}\text { Serum phosphorus } \\
(\mathrm{mg} / \mathrm{dL})\end{array}$ & $1.71 \pm 0.28$ & $1.53 \pm 0.23$ & $1.48 \pm 0.22$ & $1.34 \pm 0.29$ & $1.64 \pm 0.17$ & 0.194 \\
$\mathrm{Ca} / \mathrm{P}$ ratio & $6.83 \pm 1.28$ & $7.31 \pm 0.95$ & $7.57 \pm 1.16$ & $8.41 \pm 1.52$ & $7.79 \pm 1.47$ & 0.417 \\
\hline
\end{tabular}

Note: $\mathrm{NC}=$ normal controls; OVX-C = ovariectomized controls; OVX-E = ovariectomized rats on estradiol; OVX-S = ovariectomized rats on soybean flour; OVX-SS = ovariectomized rats on soybean sprout flour. Data were analyzed with one-way Anova. Values presented are mean \pm SD. Superscripted asterisk $\left(^{*}\right)$ shows significant differences in the row $(\mathrm{p}<0.05)$. Multiple comparisons analysis for calcium levels 
arrangement. Estrogens affect calcium bioavailability and other endocrine activities involved in bone remodeling. ${ }^{(6)}$ It has been proven that ovariectomized rats will experience the estrogen deficiency associated with menopause. ${ }^{(12)}$ Such conditions affect the absorption of calcium in the intestinal tract, ${ }^{(31)}$ which is regulated by CaSRs (calcium sensing receptors) in the parathyroid glands. CaSR activities are modulated by $\mathrm{PTH}$, calcitonin, and 1,25-dihydroxyvitamin D. ${ }^{(32)}$ Ovariectomy could also trigger a decline in the number of vitamin D receptors in the jejunum, resulting in decreased cell response signaling of vitamin $\mathrm{D}$ in the intestine, leading to a decrease in intestinal calcium absorption. ${ }^{(33)}$ Women with osteoporosis experience decreased absorption of minerals caused by a decrease of 1,25-dihydroxy vitamin $\mathrm{D}(1,25-(\mathrm{OH}) 2 \mathrm{D})$, which is known to be a regulator of bone mineral homeostasis. Low levels of 1,25- $(\mathrm{OH}) 2 \mathrm{D}$ will cause low serum calcium, yet increases PTH resulting in increased bone resorption. ${ }^{(34)}$

Soybean flour and soybean sprout flour were given based on the dose of isoflavones, but the two materials had different effects on serum calcium in the rats. These effects were likely due to several possibilities: first, the action of isoflavones (which have estrogen-like activity) providing indirect influence on calcium absorption. Isoflavones are known to play a role in maintaining bone density through the inhibition of osteoclasts, and to stimulate bone formation, so that the process could inhibit bone resorption while the bone remodeling process could continue as normal. ${ }^{(35)}$ Miao et al. ${ }^{(12)}$ reported that genistein could increase levels of serum minerals and reduce mineral excretion in the urine. The strength of the effect is dose dependent. Second, soy contains anti-nutritional compounds including phytic acids that could inhibit the absorption of minerals such as phosphorus, calcium and iron. ${ }^{(36)}$ Phytic acid levels in soy will decrease in the germination process, so phytic acid level in soybean sprouts is lower than in soybean seeds. ${ }^{(37)}$ Thus, it is possible that the group of OVX-SS rats did not experience inhibition of calcium absorption by the phytic acid. Then there is the role of bioactive components in soybeans such as vitamin $\mathrm{C}$, vitamin $\mathrm{E}$, and polyphenols that have antioxidant activity. ${ }^{(37)}$ It is known that the content of bioactive components in soybean sprouts is higher than that of soybean seeds. ${ }^{(29)}$ The antioxidative characteristics of soybean sprouts have a positive effect on rats experiencing oxidative stress due to ovariectomy. The condition affects calcium absorption as well as bone mineralization. Some researchers suggest that the postmenopausal or ovariectomized rats will experience oxidative stress indicated by the high levels of malonaldehyde (MDA) and superoxide dismutase (SOD) in serum. ${ }^{(38,39)}$

A limitation of this study was that the soybean sprouts were given to the rats in the form of whole sprouts instead of as an extract. So, it is possible that not only the isoflavones may play a role, but also other bioactive components, thus affecting theresults of this study. The study also did not analyze phytic acid levels in the soybeans and soybean sprouts, so the phytic acid intake by the rats is unknown.

The soybean sprouts in this study were prepared through the elicitation process to improve the bioactive components. The elicited soybean sprout products are potential for the maintenance of bone health, especially in postmenopausal women. The positive effects of soybean sprout consumption is strongly influenced by the amount and duration of consumption. Further research is needed to assess the potential and safety of elicited soybean sprout extract to know and ensure the potential of the bioactive components of soybean sprouts in the maintenance of bone in particular and human health in general.

\section{CONCLUSIONS}

Post-menopausal rat models, which had been treated with soybean sprout flour for six weeks at a dose of $10 \mu \mathrm{g} / \mathrm{g} \mathrm{BW} /$ day, showed higher serum calcium levels. Elicited soybean sprouts could potentially increase calcium levels in the serum of ovariectomized rats. 


\section{CONFLICT OF INTEREST}

The authors declare that there is no conflict of interest

\section{ACKNOWLEDGEMENT}

The authors would like to thank the Head and the technical implementation of laboratory, LPPT UGM for their cooperation in the accomplishment of this study.

\section{CONTRIBUTORS}

SA contributed to drafting the manuscript and the study design. SA and S contributed to acquisition of data and revising the manuscript critically for important intellectual content. SA, $\mathrm{S}, \mathrm{SN}$, and HW contributed to data and interpretation. All authors read and approved the final manuscript.

\section{REFERENCES}

1. Rauner M, Stein N, Hafbauer LC. Basics of bone biology. In: Pietschmann P, editor. Principles of osteoimmunology - molecular mechanisms and clinical applications. New York: Springer Vienna; 2012.p.1-26.

2. Clarke B. Normal bone anatomy and physiology. Clin J Am Societ Nephrol 2008;3:S131-96.

3. Kini U, Nandessh BN. Physiology of bone formation, remodeling, and metabolism. In: Fogelman I, Gnanasegaran G, Van der Wall H, editors. Radionuclide and hybrid bone imaging. Berlin: SpringerVerlag;2012.p.29-55.

4. Ross C, Taylor CL, Yaktine AL, et al, editors. Dietary reference intakes for vitamin $\mathrm{D}$ and calcium. Washington DC: The National Academies Press;2011.

5. Boonrungsiman S, Gentleman E, Carzaniga R, et al. The role of intracellular calcium phosphate in osteoblast-mediated bone apatite formation. PNAS 2012;109;14170-5.

6. $\mathrm{Pu}$ F, Chen N, Xue S. Calcium intake, calcium homeostasis and health. Food Sci Hum Wellness 2016;5:8-16.

7. Aloia J, Shieh A. Intestinal calcium absorption efficiencyin women. In: Holins MC, Watson R, Preedy V, editors. Nutrition and diet in menopause. Nutrition and health. New York: Humana Press, Totowa;2013.p.67-78.

8. Unis A, Hamzah M, Abdelzaher. Comparison of the effects of sitagliptin and estrogen on ovariectomy induced osteoporosis in rats. Int $\mathrm{J}$ Pharmacol Res 2015;1:10-8.

9. Kalita N, Choudhury BD. A cross sectional study evaluating the association of serum calcium, serum magnesium, and body mass index in premenopausal and postmenopausal women. Int J Res Med Sci 2017;51953-58.

10. Kaur S, Kaur S, Mittal N. Menopause and role of antioxidants, calcium and exercises. IOSR J Dent Med Sci 2014;13:66-8.

11. Bhale DV, Ansari HA. Study of serum calcium levels in postmenopausal women of Aurangabad district. Int J Recent Trends Sci Technol 2014;8: 332-3.

12. Miao Q, Li JG, Miao S, et al. The bone-protective effect of genistein in the animal model of bilateral ovariectomy: roles of phyto estrogens and PTH/ PTHR1 against post-menopausal osteoporosis. Int J Mol Sci 2012;13:56-70.

13. Cui Y, Deming-Halverson SL, Beeghly-Fadiel A, et al. Interactions of hormone replacement therapy, bodyweight, and bilateral oophorectomy in breast cancer risk. Hum Cancer Biol 2014;20: 1169-78. doi: 10.1158/1078-0432.CCR-132094.

14. Shabir B, Raza A, Wani P, et al. Use of soy isoflavones as alternative to hormonal therapy (HRT) for women in menopause. Int Res $\mathrm{J}$ of Medic Med Sci 2013;1:72-9.

15. Park Y, Moon HJ, Paik DJ, et al. Effect of dietary legumes on bone-specific gene expression in ovariectomized rats. Nutr Res Pract 2013;7:18591. http://dx.doi.org/10.4162/nrp/2013.7.3.185.

16. Akao M, Abe M, Sato N, et al. Prevention of osteoporosis by oral administration of phytateremoved and deamidated soybean b-conglycinin. Int J Mol Sci 2015;16:2117-29.

17. He FJ, Chen JQ. Consumption of soybean, soy foods, soy isoflavones and breast cancer incidence: differences between Chinese women and women in Western countries and possible mechanisms. Food Sci Human Wellness 2013;2: 146-61. http://dx.doi.org/10.1016/j.fshw.2013. 08.002 .

18. Rumiyati, James AP, Jayasena V. Effect of germination on the nutritional and protein profile of Australian sweet lupin (Lupinus angustifolius L.). Food Nutr Sci 2012;3:621-6.

19. Syah AS, Zeb A, Masood T, et al. Effects of sprouting time on biochemical and nutritional 
qualities of Mungbean varieties. African J Agric Res 2011;1:5091-98.

20. Mugisha J, Asekova S, Kulkarni KP, et al. Evaluation of crude protein, crude oil, total flavonoid, total polyphenol content and DPPH activity in the sprouts from a high oleic acid soybean cultivar. Korean J Agricultural Science 2016;43:723-73. DOI: https://doi.org/10.7744/ kjoas.20160075.

21. Sirotkin AV, Harrath AH. Phytoestrogens and their effects. Eur J Pharmacol 2014;741:230-6. http://dx.doi.org/10.1016/j.ejphar.2014.07. 057.

22. Baenas B, García-Viguera C, Moreno DA. Elicitation: a tool for enriching the bioactive composition of foods. Molecules 2014;19: 13541-63. doi: 10.3390/molecules190913541.

23. Saini RK, Devi MKA, Parvatam G, et al. Augmentation of major isoflavones in Glycine $\max$ L. through the elicitor-mediated approach. Acta Bot Croat 2013;72:311-22.

24. Aminah S, Mukaromah HA. Peningkatan senyawa antioksidan dan aktivitas antioksidan kedelai melalui pengecambahan dengan elisitasi $\mathrm{NaCl}$. Prosiding Seminar Nasional dan Presentasi Hasil-hasil Penelitian Bidang Kesehatan. Aptikes Indonesia; 2013 Dec 21; Fatawa Publishing;2013.p.162-72.

25. Swigonska S, Amarowicz R, Król A, et al. Influence of abiotic stress during soybean germination followed by recovery on the phenolic compounds of radicles and their antioxidant capacity. Acta Soc Bot Pol 2014;83:209-18. doi: 10.5586/ asbp.2014.026

26. Komori T. Animal models for osteoporosis. Eur J Pharmacol 2015;759:287-94. doi: 10.1016/j.ejphar. 2015.03.028.

27. Supranto J. Teknik sampling untuk survey dan eskperimen. Jakarta: PT Rineka Cipta; Cetakan Keempat;2007.p.225-52.

28. Hartiningsih, Anggraini D, Aji D. The response of metafisis distal femur ovariectomized rats consuming calcitiriol supplement. Kedokteran Hewan 2012;6:92-7.

29. Rusydi MRM, Azrina A. Effect of germination on total phenolic, tannin, and phytic acid content in soy bean and peanut. Int Food Res J 2012;19: 67-7.
30. Shin JM, Shin E, Jo TH, et al. Effect of Hwanggum (Scutellaria Radix) extract on ovariectomized osteoporotic rats. Food Sci Biotechnol 2013;22: 493-9.

31. Abu-Taha M, Rius C, Hermenigildo C, et al. Menopause and ovarictomy cause a low Grade of systemic inflammation that may be prevented by chronic treatment with low doses of estrogen or losartan. Immunology 2009;183:1393-402.

32. Poulsen RC, Kruger CM. Soy phytoestrogens: impact on postmenopausal bone loss and mechanisms of action. Nutr Rev 2008;4:161021.

33. Lips P. Vitamin D and bone health. In: Burckhardt P, Dawson-Hubhes B, Weaver C, editors. Nutritioal influences on bone health. Lausanne, Switzerland: Springer 2010.p.115-25.

34. Jumaa SS, Ezzat-Zadeh Z, Khalil DA, et al. Soy protein with or without isoflavones failed to preserve bone density in gonadal hormonedeficient male rat model of osteoporosis. Nutr Res 2012;32:604-700.

35. Dardami TS, Nurdiana, Nurahmawati E. The effect of blackeyed peason osteoblas and osteoclast of rat with ovariectomy. J Kedokteran Brawijaya 2011;26:151-5.

36. Al Hasan SM, Hassan M, Saha S, et al. Dietary phytate intake inhibits the bioavailability of iron and calcium in thediets of pregnant women in rural Bangladesh: a cross-sectional study. BMC Nutrition 2016;2:1-10.

37. Xue Z, Wang C, Zhai L, et al. Bioactive compounds and antioxidant activity of mung bean (Vigna radiata L.), soybean (Glycine max L.) and black bean (Phaseolus vulgaris L.) during the germination process. Czech J Food Sci 2016; 34:68-78.

38. Jiang JX. Reactive oxygen species and oxidative stress in osteoclas to genesis, skeletal aging and bone diseases. J Bone Miner Metab 2015;33: 359-70.

39. Rodrigues MFC, Stotzer US, Domingos MM, et al. Effects of ovariectomy and resistance training on oxidative stress markers in the rat liver. Clinics 2013;68:1247-54. 